Journal of Animal and Veterinary Advances 10 (3): 316-321, 2011

ISSN: $1680-5593$

(C) Medwell Journals, 2011

\title{
Epidemiology of Subclinical Mastitis and Their Antibacterial Susceptibility in Smallholder Dairy Farms, Chiang Mai Province, Thailand
}

\author{
Witaya Suriyasathaporn \\ Faculty of Veterinary Medicine, Chiang Mai University, \\ 50100 Chiang Mai, Chiang Mai Province, Thailand
}

\begin{abstract}
The objectives of this study were to identify the bacteria causing subclinical mastitis at the beginning of the rainy season to define the factors associated with subclinical mastitis caused by various pathogens and to identify antibiotic susceptibility and resistance. About 42 farms from the Mae-On Dairy Cooperative participating in the Herd Health Management Program (HHPM), Faculty of Veterinary Medicine, Chiang Mai University were included in the study. The study was conducted in June, 2008. From the protocol of HHPM, all farms had to collect a milk sample from each milking cow for measurement of Somatic Cell Counts (SCC) once a month. At the cut-off point of SCC $=200,000$ cells $\mathrm{mL}^{-1}$ the cows were deemed to haveintramammary infection. Cows in 3 groups were checked for subclinical mastitis in quarter levels using the California mastitis test within 2 weeks after SCC measurement. A cow with CMT score $\geq+1$ for at least one quarter was identified as a subclinical mastitis cow and was included into the study. Milk samples from subclinical mastitis quarters were collected with aseptic techniques. The fisher exact $\chi^{2}$-tests were used to evaluate the association of pathogens with antibiotic resistant and the associated factors. The significant levels were defined at $\mathrm{p}<0.05$. In total, 133 quarters from 68 cows and 22 dairy farms were included in the study. C. bovis (28\%) and Coagulase Negative Staphylococci (CNS) (28\%) were the main bacteria isolated in this study. Stap. aureus (8\%) and St. agalactiae (2\%) as contagious pathogens were at low levels. An occurrence of subclinical mastitis from $S$. aureus was significantly associated with subclinical mastitis status in which most $S$. aureus subclinical mastitis showed chronic status of subclinical mastitis. Most subclinical cases occurred during late lactation (54\%). Occurrences of subclinical mastitis from Stap. aureus and C. bovis were associated with period of lactation $(\mathrm{p}<0.05$ ). About 99 bacterial identifications were used for antibiotic susceptibility test. Bacteria that were significantly associated with resistant patterns were St. uberis, S. aureus and S. dysgalactaie. Subclinical mastitis with St. uberis was resistant to most antibiotics $(\mathrm{p}<0.05)$; subclinical mastitis with Stap. aureus and CNS wassusceptible for most antibiotics.
\end{abstract}

Key words: Subclinical mastitis, pathogens, antibiotic resistant, somatic cell counts, associated factor, chronic status

\section{INTRODUCTION}

Mastitis is a costly disease in the dairy industry through decreased production, discard of milk, drug and veterinary expense, extra labor and increased rate of cow replacement (Bartlett et al., 1990). A subclinical form is the most prevalent type of mastitis; it can be a reservoir of infection that can spread micro-organisms to other cows and can develop into a clinical case. Bacterial intramammary infection is the most common cause of mastitis. The various bacterial species causing mastitis are different depending on geographic area, management and environment. Many epidemiological studies on mastitis-causing micro-organisms in western countries have reported that the prevalence of the classical contagious bacteria such as $S$. aureusand $S$ t. agalactiae has decreased but that CNS and C. bovis considered to be minor mastitis pathogens have become more common (Makovec and Ruegg, 2003; Osteras et al., 2006; Pittkala et al., 2004).

Pathogens causing subclinical mastitis are quite different in tropical countries. $S$. aureus has shown more predominance than environmental pathogens (Mekonnen et al., 2005; Shitandi and Kihumbu, 2004). Some studies in Thailandhave reported that minor pathogens such as CNS and Streptococcus sp. have become dominant pathogens (Ajariyakhajorn et al., 2003; Boonyayatra et al., 2007; Boonyayatra and Chaisri, 2004). Intramammary Infection (IMI) involvesmany risk factors. The season has been reported as influencing occurrence of IMI in western countries. Thailand has a different climate and different seasonal patterns but information 
relating its seasonal risk factor is scant. Antimicrobial agents play an important role in the treatment and control of mastitis. Therapy decisions are usually based on previous susceptibility information for the herd. Susceptibility patterns of antibacterial agents depend on the type of causal micro-organisms. The different resistancepatterns among various mastitis pathogens have been widely reported (Gentilini et al., 2002; Mekonnen et al., 2005; Pittkala et al., 2004). However, information on the susceptible or resistant patterns of mastitis pathogens in the small dairy farm in this area is limited. Therefore, the objectives of this study were to identify the bacteria causing subclinical mastitis at the beginning of the rainy season to define the factors associated with subclinical mastitis caused by various pathogens and to identify the antibiotic susceptibility and resistance.

\section{MATERIALS AND METHODS}

Farm selection: About 42 farms from the Mae-On Dairy Cooperative participating in the Herd Health Management Program, Faculty of Veterinary Medicine, Chiang Mai University were included in the study. All farms were small-holder dairy farms with $<20$ milking cows per farm and using budget-type milking machines with an average of 8 cows/machine set.

Most cows were fed post-harvest corn stem and straw ad lib and concentrates according to their milk production and the vast majority of the cows were crossbred Holstein-Friesian. Veterinarians and paraveterinarians were available on call as health and reproductive consultants (the para-veterinarians were animal health and reproduction volunteers trained by the Department of Livestock Development, Ministry of Agriculture and Cooperatives, Thailand from either the private sector or the Satellite Animal Hospital, Faculty of Veterinary Medicine, Chiang Mai University.

Cow and samples collection: The study was conducted in June, 2008. From the protocol of HHPM, all farms had to collect milk samples from each milking cow for measurement of Somatic Cell Counts (SCC) once a month. At the cut-off point of $\mathrm{SCC}=200,000$ cells $\mathrm{mL}^{-1}$ the cows were deemed to have intramammary infection. Based on the results of SCC at May and June, cows were defined into acute stage (ACUTE) for cows that had $\mathrm{SCC}<200,000$ cells $\mathrm{mL}^{-1}$ in May and $>200,000$ cells mL $^{-1}$ in June, chronic stage (CHRONIC) for cows that had SCC $>200,000$ cells $\mathrm{mL}^{-1}$ in both May and June and other stage (OTHER) for cows that had $\mathrm{SCC}<200,000$ cells $^{-1}$ in June but had SCC $>200,000$ cells for the previous months. Cows in the three groups were checked for subclinical mastitis in quarter levels using California mastitis test within 2 weeks after SCC measurement. The reaction was interpreted as follows: score $0=$ no reaction; trace $=$ slight slime which disappears with continued swirling; $+1=$ distinct slime but without gel formation; +2 = immediate formation of gel which moves as a mass during swirling; $+3=$ gel develops a convex surface and adheres to the bottom of the paddle.

A cow with a CMT score $z+1$ inat least one quarter was identified as a subclinical mastitis cow and was included in the study. Milk samples from subclinical mastitis quarters were collected with aseptic techniques in accordance with National Mastitis Council guidelines (NMC, 1999). Briefly, an udder and teat were cleaned with disinfectant. The teat ends were scrubbed with cotton balls moistened with $70 \%$ ethanol solution until they were no longer visibly dirty. The first stream of milk was discarded before collecting the samples into a sterile test tube. The samples were kept in cool temperature and were transported to the laboratory immediately for bacterial identification. The data on owner, cow identification, quarter, sampling and date of sampling were recorded.

Bacterial identification: Microbiological examination was performed according to the standards described in the National Mastitis Council's guideline (NMC, 1999). About $10 \mu \mathrm{L}$ of an individual quarter milk sample was cultured on $5 \%$ bovine blood agar plates and MacConkey agar plates. Plates were incubated at $37^{\circ} \mathrm{C}$ for $24-48 \mathrm{~h}$. Bacterial colonies were identified based on gross morphology, number of colonies and hemolytic pattern.

Appropriate tests were performed on the colonies isolated to identify the pathogens including gram staining and a catalase test to distinguish between streptococci and staphylococci. The hemolytic patterns and coagulase reaction with rabbit plasma were used to distinguish between $S$. aureus and CNS and the esculin hydrolysis and CAMP reaction were used to differentiate Streptococcus agalactiae and environmental streptococci. C. bovis was identified by using culture characteristic on blood agar, motility and catalase reaction test. Gram-negative bacteria were identified to Enterococci sp. using culture morphology on MacConkey agar (Merk, Germany), lactose fermentation, motility and reaction in triple sugar iron.

Other colony types were grouped as other microorganisms. Degree of confidence in diagnosing an infection was classified asnot significant, questionably significant, probably significant or highly significant based on the National Mastitis Council's guidelines (NMC, 1999). Samples that contained three or more 
bacterial species were considered to be contaminated. However, isolates of either St. agalactiae or S. aureus were always defined as intramammary infection (NMC, 1999).

Susceptibility testing: The highly significant isolates were tested for antibiotic susceptibility by the agar disk diffusion method in accordance with the standard in NMC guideline. Firstly, all isolates were checked for purity by subculturing on proper media. About 3-5 colonies of pure isolated pathogens were picked up and suspended in trypticase soy broth and incubated at $37^{\circ} \mathrm{C}$ for $2-8 \mathrm{~h}$ to increase amounts of bacteria. The standard turbidity of bacterial suspension was adjusted to a turbidity equivalent to a $0.5 \mathrm{McF}$ arland standard. The entire surface of agar plates was inoculated by using sterile cotton swab. Disks containing $10 \mu \mathrm{g}$ of ampicillin, $30 \mu \mathrm{g}$ of cloxacillin, $30 \mu \mathrm{g}$ of cephazolin, $10 \mu \mathrm{g}$ of gentamicin, $10 \mu \mathrm{g}$ of tetracyclineand $10 \mu \mathrm{g}$ of sulfa-trimethroprim were placed onto the agar surface and gently pressed to ensure contact. Plates were incubated at $37^{\circ} \mathrm{C}$ for $24 \mathrm{~h}$. Subsequently, the diameter of the zone of inhibition around the disk was measured. The isolated microorganisms were categorized to susceptibility and resistance according to methods and criteria described by National Committee for Clinical Laboratory Standards (NCCLS, 2002).

Statistical analyses: Contaminated milk samples were excluded from statistical analysis when quarters with any bacteria were defined as quarters with intramammary infection. Factors associated with subclinical mastitis in the rainy season included status of subclinical mastitis, levels of SCC: ( $\mathrm{HIGH}, \mathrm{SCC}$ in June $<400,000$ cells cc$^{-1}$ and LOW, SCC in June $>400,000$ cells cc ${ }^{-1}$ ), levels of 4 months averaged SCC $\left(\mathrm{HIGH}_{\mathrm{av}}, \mathrm{SCC}\right.$ in June $<400,000$ cells cc $^{-1}$ and $\mathrm{LOW}_{\mathrm{av}}, \mathrm{SCC}$ in June $>400,000$ cells $\mathrm{cc}^{-1}$ ) and 4 lactation periods: days in milk at $<100$ (EARLY), 100-200 (MID), $>200$ (LATE). Frequencies of quarters with subclinical mastitis cows were described as percentages. From the results of susceptibility testing, percentages of resistance for all bacteria were described and analyzed separately.

Antibiotic resistant subclinical mastitis case (RESIST) was defined when the case had $<4$ antibiotic susceptibility tests out of 6 . Effects of associated factors, bacterial resistance and antibiotic susceptibility on cloxacillin, gentamicin, tetracycline and sulfa-trimethroprimgentam as the most used antibiotic for mastitis in this area were analyzed separately for all pathogens including $S$. aureus,
Step. uberis, Step. dysgalactiae, CNS and C. bovis. The Fisher exact chi-square tests were used to evaluate the association of pathogens with antibiotic susceptibility, RESIST and the associated factors. The significant levels were defined at $\mathrm{p}<0.05$.

\section{RESULTS AND DISCUSSION}

In total, 133 quarters from 68 cows and 22 dairy farms were included in the study. Frequencies of bacteria isolation from subclinical mastitis cases during the rainy season were shown in Fig. 1. C. bovis $(28 \%)$ and CNS $(28 \%)$ were the most common bacteria isolated in this study. S. aureus $(8 \%)$ and St. agalactiae $(2 \%)$ as contagious pathogens were atlow levels. Environmental streptococci including St. uberis $(5 \%)$ and St. dysgalactiae (6\%) were found at approximately $11 \%$.

Associations of subclinical mastitis status are shown in Table 1. An occurrence of subclinical mastitis from $S$. aureus was significantly associated with subclinical mastitis status in which most $S$. aureus subclinical mastitis showed chronic status. Levels of both recent SCC and averaged SCC were associated with occurrences of $S$. aureusand St. dysgalactaie, respectively (Table 2). Cows with recently high SCC $\left(>400,000\right.$ cells $\left.\mathrm{mL}^{-1}\right)$ were associated with Stap. aureus but cows with low levels ( $<400,000$ cells $\mathrm{mL}^{-1}$ ) of 4 months averaged SCC were associated with subclinical mastitis from St. dysgalactaie. Most subclinical cases occurred during late lactation (54\%). Occurrences of subclinical mastitis from S. aureus and $C$. bovis were associated with period of lactation $(\mathrm{p}<0.05)$. Subclinical mastitis from S. aureus mostly occurred during mid lactation $(20.83 \%)$ but from C. bovis mostly occurred in late lactation Table 3.

From the overall antibiotic susceptibility testing ( $\mathrm{n}=99$ ), cephalosporin wasmost susceptible for subclinical mastitis pathogens (95\%) excluding 3 cases from the other pathogens group and a case from coliform bacteria. Percentages of antibiotic susceptibility for

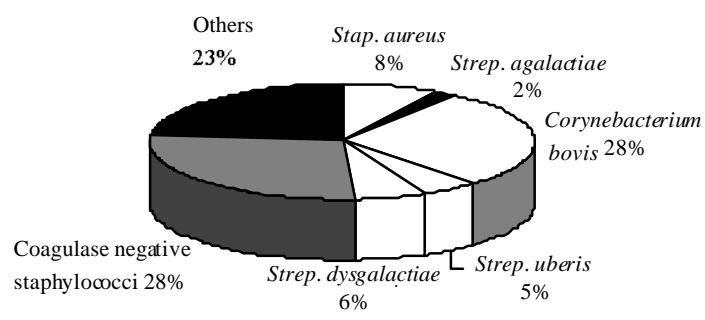

Fig. 1: Distribution of bacterial isolation from subclinical mastitis cases $(n=133)$ 
Table 1: Associations of subclinical mastitis status as CHRONIC, ACUTE and OTHER on occurrences of subclinical mastitis from specified pathogens

\begin{tabular}{|c|c|c|c|c|c|c|c|}
\hline \multirow[b]{2}{*}{ Pathogens } & \multicolumn{2}{|c|}{ CHRONIC $(\mathrm{N}=46)$} & \multicolumn{2}{|c|}{$\operatorname{ACUTE}(\mathrm{N}=25)$} & \multicolumn{2}{|c|}{ OTHER $(\mathrm{N}=40)$} & \multirow[b]{2}{*}{$\mathrm{p}$ value } \\
\hline & $\mathrm{n}$ & $(\%)$ & $\mathrm{n}$ & $(\%)$ & $\mathrm{n}$ & $(\%)$ & \\
\hline S. aureus & 7 & 15.22 & 1 & 4.00 & 0 & 0 & 0.02 \\
\hline St. uberis* & 2 & 4.35 & 0 & 4.17 & 2 & 5 & 0.68 \\
\hline St dysgalactiae & 3 & 6.52 & 1 & 5.00 & 2 & 5 & 1.00 \\
\hline CNS & 10 & 21.74 & 5 & 20.00 & 16 & 40 & 0.13 \\
\hline C. bovis & 12 & 26.09 & 10 & 40.00 & 12 & 30 & 0.47 \\
\hline
\end{tabular}

*Missing data $=22$ caused by unspecified classes

Table 2: Associations of recent Somatic Cell Count (SCC) and 4 month averaged SCC on occurrences of subclinical mastitis from specified pathogens

\begin{tabular}{|c|c|c|c|c|c|}
\hline \multirow[b]{2}{*}{ Pathogens } & \multicolumn{2}{|c|}{ LOW } & \multicolumn{2}{|c|}{ HIGH } & \multirow[b]{2}{*}{$\mathrm{p}$ value } \\
\hline & $\mathrm{n}$ & $(\%)$ & $\mathrm{n}$ & $(\%)$ & \\
\hline \multicolumn{6}{|c|}{ Recent somatic cell count" } \\
\hline S. aureus & 3 & 3.85 & 8 & 14.55 & 0.05 \\
\hline St uberis & 4 & 5.13 & 3 & 5.45 & 1.00 \\
\hline St dysgaloctice & 6 & 7.69 & 2 & 3.64 & 0.47 \\
\hline CNS & 26 & 33.33 & 11 & 20.00 & 0.12 \\
\hline C. bovis & 21 & 26.92 & 16 & 29.09 & 1.00 \\
\hline \multicolumn{6}{|c|}{ Averaged somatic cell count $*$ * } \\
\hline S. aureus & 6 & 7.14 & 5 & 10.20 & 0.53 \\
\hline St. uberis & 4 & 4.76 & 3 & 6.12 & 0.71 \\
\hline St dysgalactiae & 8 & 9.52 & 0 & 0.00 & 0.03 \\
\hline CNS & 27 & 32.14 & 10 & 20.41 & 0.16 \\
\hline C. bovis & 20 & 23.81 & 17 & 34.69 & 0.23 \\
\hline
\end{tabular}

*Total number of low $\left(<400,000\right.$ cells $\left.\mathrm{mL}^{-1}\right)$ and high $\left(>400,000\right.$ cells $\left.\mathrm{mL}^{-1}\right)$ were 78 and 55 , respectively. **Total number of low $\left(<400,000\right.$ cells $\left.\mathrm{mL}^{-1}\right)$ and high $\left(>400,000\right.$ cells $\left.\mathrm{mL}^{-1}\right)$ were 84 and 49 , respectively

Table 3: Effects of period of lactation as days in milk $<100$ (early), 100-200 (mid) and $>200$ (late) on occurrences of subclinical mastitis from specified

\begin{tabular}{|c|c|c|c|c|c|c|c|}
\hline \multirow[b]{2}{*}{ Species } & \multicolumn{2}{|c|}{ Early $(\mathrm{N}=33)$} & \multicolumn{2}{|c|}{$\operatorname{Mid}(N=24)$} & \multicolumn{2}{|c|}{ Late $(\mathrm{N}=72)$} & \multirow[b]{2}{*}{$p$-value } \\
\hline & $\mathrm{n}$ & $(\%)$ & $\mathrm{n}$ & $(\%)$ & $\mathrm{n}$ & $(\%)$ & \\
\hline S. aureus & 3 & 9.09 & 5 & 20.83 & 3 & 4.00 & 0.02 \\
\hline St. uberis* & 3 & 9.09 & 1 & 4.17 & 3 & 4.00 & 0.50 \\
\hline St dysgalactice & 4 & 12.12 & 0 & 0.00 & 4 & 5.33 & 0.18 \\
\hline CNS & 11 & 33.33 & 6 & 25.00 & 20 & 26.67 & 0.75 \\
\hline C. bovis & 4 & 12.12 & 5 & 20.83 & 27 & 36.00 & 0.02 \\
\hline
\end{tabular}

*missing value $=1$

Table 4: Percentages of antibiotic susceptibility on pathogens causing subclinical mastitis ( $\mathrm{n}=99$ )

\begin{tabular}{|c|c|c|c|c|c|c|c|c|c|c|}
\hline \multirow[b]{2}{*}{ Antibiotics } & \multicolumn{2}{|c|}{ S. aureus } & \multicolumn{2}{|c|}{ St. uberis } & \multicolumn{2}{|c|}{ St. dysgalactiae } & \multicolumn{2}{|l|}{ CNS } & \multicolumn{2}{|c|}{ C. bovis } \\
\hline & $\mathrm{s}$ & $\mathrm{R}$ & $\mathrm{s}$ & $\mathrm{R}$ & $\mathrm{s}$ & $\mathrm{R}$ & $\mathrm{s}$ & $\mathrm{R}$ & $\mathrm{s}$ & $\mathrm{R}$ \\
\hline Cloxacillin & $23.4^{* * *}$ & $0.0^{* * * *}$ & $2.1^{*}$ & $11.5^{*}$ & 10.6 & 3.9 & 20.3 & 19.2 & 17.0 & 28.9 \\
\hline Gentamicin & $17.5^{\text {*** }}$ & $2.4^{* * *}$ & $1.8^{* * *}$ & $14.3^{\text {*** }}$ & 7.0 & 7.1 & $33.3^{\text {*** }}$ & $2.4^{* * *}$ & 28.1 & 16.7 \\
\hline Oxytetracycline & $20.0^{* * *}$ & $3.7^{* * *}$ & $2.2^{*}$ & $11.1^{*}$ & $2.2^{*}$ & $11.1^{*}$ & $37.8^{* * * *}$ & $5.6^{* * * *}$ & 17.8 & 27.8 \\
\hline Sulfa-trimetroprim & $24.4^{* * *}$ & $0.0^{* * *}$ & $2.2^{*}$ & $11.1^{*}$ & $2.2^{*}$ & $11.1^{*}$ & $28.9^{* * * *}$ & $13.0^{\text {**** }}$ & 33.3 & 14.8 \\
\hline $\begin{array}{l}\text { At least } 4 \text { susceptible } \\
\text { out of } 6 \text { antibiotics }\end{array}$ & $23.4^{* * *}$ & $0.0^{* * *}$ & $0.0^{* * *}$ & $13.5^{* * *}$ & 6.4 & 7.7 & $31.9^{* * *}$ & $9.6^{* * *}$ & 23.4 & 23.1 \\
\hline
\end{tabular}

ampicillin, cloxacillin, tetracycline, gentamycin and sulfa-trimetroprim were $55.1,47.5,45.5,57.6$ and $45.5 \%$, respectively. Therefore, the efficiency of cephalosporin in this study was $100 \%$ susceptible for St.uberis, S. aureus, CNS, St. dysgalactiae and C. bovis. For ampicillin, there was no significant association between antibiotic susceptibility on occurrences of subclinical mastitis from specified pathogens. Associations between antibiotic susceptibility for cloxacillin, gentamicin, tetracycline and sulfa-trimetrophim on pathogens causing subclinical mastitis were shown in Table 4. Most antibiotics tested here except cloxacillin were susceptible to $S$. aureus causing subclinical mastitis. Except for cephalosporin, most CNS were susceptible to gentamicin $(\mathrm{p}<0.01)$ and tetracycline $(\mathrm{p}<0.01)$ and C. bovis was susceptible to sulfatrimetroprim. Bacteria that were significantly associated with the resistant pattern (4 susceptible out of 6 antibiotics) were St. uberis, Staph. aureus and St. dysgalactaie. Subclinical mastitis with St. uberis was resistant to most antibiotics $(p<0.05)$; subclinical mastitis with $S$. aureus and CNS were susceptible for most antibiotics. Environmental C. bovis $(28 \%)$ and CNS $(28 \%)$ were the most commonly isolated bacteriain this study. This is in agreement with previous studies in USA and Europewhere CNS, $S$. sp. which is not $S$. aureus were the predominant bacteria causing mastitis 
(Makovec and Ruegg, 2003; Pittkala et al., 2004). In a recent study on dairy cows in Brandenburg, Germany, CNS and C. bovis were the pathogens most frequently isolated in the study on prevalence of mastitis pathogens and their resistance against antimicrobial agents. There is disagreement with many reports on studies in Thailand (Ajariyakhajorn et al., 2003; Boonyayatra et al., 2007; Boonyayatra and Chaisri, 2004). However in Northeastern Thailand, Ethiopia and Kenya, $S$. aureus was the most common cause of subclinical mastitis (Mekonnen et al., 2005; Shitandi and Kihumbu, 2004). CNS and C. bovis were common isolated bacteria in the current study. These results were similar to the previous report from Finland (Pittkala et al., 2004).

Subclinical mastitis cases from $S$. aureus were mostly chronic caseshaving an increase of SCC $>200,000$ cells $\mathrm{mL}^{-1}$ for 2 months. In the study, we also found the differences of SCC on mastitis pathogen causing subclinical mastitis (Table 2 ). Cows with recently high SCC $\left(>400,000\right.$ cells $\left.\mathrm{mL}^{-1}\right)$ were associated with S. aureus but cows with low levels $\left(<400,000\right.$ cells $\left.\mathrm{mL}^{-1}\right)$ of 4 months averaged SCC were associated with subclinical mastitis from St. dysgalactaie. In the view, there is a limited number of studies on pathogen-specific subclinical mastitis and SCC. Few studies have investigated pathogen-specific clinical mastitis and its effects on SCC curves.

However, De Haas et al. (2004) estimated associations between pathogen-specific cases of clinical mastitis and SCC patterns based on deviations from a typical curve for SCC during lactation. They found that clinical $E$. coli mastitis was associated with short peaks in SCC whereas $S$. aureus was associated with long-lasting increases in SCC. No particular SCC patterns were found for St. dysgalactiae and St. uberis. Chaffer et al. (1999) found that CNS were associated with increased SCC and caused chronic infections in heifers similar to those caused by $S$. aureus. These results indicate that breeding for lower SCC is more likely to reduce the number of clinical mastitis due to bacteria such as $S$. aureus and CNS as against bacteria such as $E$. coli.

In this study, $S$. aureus was likely to be susceptible to most antibiotics testing in vitro. Selection of antibiotics for treatment based on in vitro susceptibility to antibiotics is no guarantee for treatment success in vivo. According to one study in vitro testing can be used as a predictor for cure for $S$. aureus infections of $<2$ weeks duration but not for chronic intramammary infection (the intramammary infection of $>4$ weeks (Owens et al., 1997). $S$. aureus is susceptible to a variety of antibiotics in vitro. However, farmers often complain that in vivo cure rates are disappointing. Several factors including the ability of $S$. aureus to survive inside neutrophils (Mullarky et al., 2001; Yancey et al., 1991) to form small-colony variants or L-forms (Brouillette et al., 2004; Owens and Nickerson,
1989) to induce fibrosis and formation of microabscesses (Erskine et al., 2003; Sordillo et al., 1989; Ziv and Storper, 1985 ) and to invade into mammary epithelial cells (Dego et al., 2002; Lammers et al., 2000) are potential contributors to the poor response of chronic $S$. aureus to antimicrobial treatment. Excepting for cephalosporin, antibiotic susceptibility tests showed that CNS was more susceptible for gentamicin and tetracycline. For environmental streptococci especially St. uberis, most antimicrobials used in this study had high levels of resistance (Table 4).

These results are higher than those in previous reports (Busato et al., 2000; Erskine et al., 2002; Mekonnen et al., 2005). The high percentage of resistance to penicillin is probably related to its being the most common antibiotic available on themarket and consequently the first choice. Furthermore, widely used sulfa-trimethroprim, tetracycline and gentamicin to treat gastro-intestinal and other diseases in cattle have probably developed the resistance of these antimicrobial agents.

\section{CONCLUSION}

The observation of subclinical mastitis during the rainy season has shown that most pathogens isolated were coagulase negative staphylococci and $C$. bovis. Occurrences of subclinical mastitis from $S$. aureus were associated with increased SCC $>200,000$ cells $\mathrm{mL}^{-1}$ for 2 months as chronic intramammary infection and also with increased recent $\mathrm{SCC}>400,000$ cells $\mathrm{mL}^{-1}$. St. dysgalactiae was associated with increase of 4 month averaged $\mathrm{SCC}>400,000$ cells $\mathrm{mL}^{-1}$. Most mastitis pathogens were susceptible to cephalosporin. S. aureus and CNS were susceptible to most antibiotic testing in vitro in this study but Strepuberis was resistant to antibiotic susceptibility testing. Coagulase negative staphylococci were mostly susceptible to gentamicin and tetracycline.

\section{ACKNOWLEDGEMENT}

This study was supported by agrant from the National Research Council of Thailand.

\section{REFERENCES}

Ajariyakhajorn, K., S. Samngamnim, T. Boonsern, C. Inchaisri, T. Thirapatsakun and R.J. Farnsworth, 2003. Mastitis in small dairy holders of Nakornpathom Provinces, Thailand. Proceedings of the 11th International Symposium of the Word Association of Veterinary Laboratory Diagnosticians and OIE Seminar on Biotechnology, Nov. 9-13, Bangkok, Thailand, pp: 120-121. 
Bartlett, P.C., G.Y. Miller, C.R. Anderson and J.H. Kirk, 1990. Milk production and somatic cell count in Michigan Dairy Herds. J. Dairy Sci., 73: 2794-2800.

Boonyayatra, S. and W. Chaisri, 2004. Incidence and prevalence of subclinical mastitis in small holder dairy farms of Chiang Mai Province, Thailand. Chiang Mai Vet. J., 2: 25-30.

Boonyayatra, S., J. Thaboonpeng, K. Kreausukon and W. Suriyasathaporn, 2007. Anitimicrobial resistance of mastitis-associated bacteria in lactating dairy cows in Chiang, Mai Province. Chiang Mai Vet. J., 5: $135-145$.

Brouillette, E., A. Martinez, B.J. Boyll, N.E. Allen and F. Malouin, 2004. Persistence of a Staphylococcus aureus small-colony variant under antibiotic pressure in vivo. FEMS Immunol. Med. Microbiol., 41: 35-41.

Busato, A., P. Trachsel, M. Challibaum and J.W. Blum, 2000. Udder health and risk factors for subclinical mastitis in organic dairy farms in Switzerland. Preventive Vet. Med., 44: 205-220.

Chaffer, M., G. Leitner, M. Winkler and A. Glickman, 1999. Coagulase-negative staphylococci and mammary gland infections in cows. J. Vet. Med., B46: 707-712.

De Haas, Y., R.F. Veerkamp, H.W. Barkema, Y.T. Grohn and Y.H. Schukken, 2004. Associations between pathogen-specific cases of clinical mastitis and somatic cell count patterns. J. Dairy Sci., 87: 95-105.

Dego, O.K., J.E. van Dijk and H. Nederbragt, 2002. Factors involved in the early pathogenesis of bovine Staphylococcus aureus mastitis with emphasis on bacterial adhesion and invasion-A review. Vet. Q., 24: 181-198.

Erskine, R.J., R.D. Walker, C.A. Bolin, P.C. Bartiett and D.G. White, 2002. Trends in antibacterial susceptibility of mastitis pathogens during a sevenyear period. J. Dairy Sci., 85: 1111-1118.

Erskine, R.J., S. Wagner and F.J. DeGraves, 2003. Mastitis therapy and pharmacology. Vet. Clin. North Am. Food Anim. Pract., 19: 109-138.

Gentilini, E., G. Denamiel, A. Betancor, M. Rebuelto, M. Rodriguez Fermepin and De R.A. Torrest, 2002. Antimicrobial susceptibility of coagulase-negative staphylococci isolated from bovine mastitis in Argentina. J. Dairy Sci., 85: 1913-1917.

Lammers, A., E. Kruijt, C. van de Kuijt, P.J.M. Nuijten and H.E. Smith, 2000. Identification of Staphylococcus aureus genes expressed during growth in milk: A useful model for selection of genes important in bovine mastitis. Microbiology, 146: 981-987.

Makovec, J.A. and P.I. Ruegg, 2003. Antimicrobial resistance of bacteria isolated from dairy cow milk samples submitted for bacterial culture: 8,905 samples (1994-2001). J. Am. Vet. Med. Assoc., 222: 1582-1589.
Mekonnen, H., S. Workineh, M. Bayleyegn, A. Moges and K. Tadele, 2005. Antimicrobial susceptibility profiles of mastitis isolates from cows in three major Ethiopian dairies. Revue de Med. Vet., 156: 391-394.

Mullarky, I.K., C. Su, N. Frieze, Y.H. Park and L.M. Sordillo, 2001. Staphylococcus aureus agr genotypes with enterotoxin production capabilities can resist neutrophil bactericidal activity. Infect. Immun., 69: 45-51.

NCCLS, 2002. Performance Standards for Antimicrobial Disk and Dilution Susceptibility Tests for Bacteria Isolated from Animals: Approved Standard. 2nd Edn., National Committee for Clinical Laboratory Standards, Wayne, PA., USA., ISBN: 1-56238-461-9.

NMC., 1999. Laboratory Handbook on Bovine Mastitis. National Mastitis Council Inc., Madison, WI.

Osteras, O., L. Solverod and O. Reksen, 2006. Milk culture results in a large norwegian survey-effects of season, parity, days in milk, resistance and clustering. J. Dairy Sci., 89: 1010-1023.

Owens, W.E. and S.C. Nickerson, 1989. Morphologic study of Staphylococcus aureus L-form, reverting and intermediate colonies in situ. J. Clin. Microbiol., 27: 1382-1386.

Owens, W.E., C.H. Ray, J.L. Watts and R.J. Yancey, 1997. Comparison of success of antibiotic therapy during lactation and results of antimicrobial susceptibility test for bovine mastitis. J. Dairy Sci., 80: 313-317.

Pittkala, A., M. Haveris, S. Pyorala, V. Myllys and T.H. Buzalski, 2004. Bovine mastitis in finland 2001 prevalence, distribution of bacteria and antimicrobial resistance. J. Dairy Sci., 87: 2433-2442.

Shitandi, A. and G. Kihumbu, 2004. Assessment of the California mastitis test usage in smallholder dairy herds and risk of violative antimicrobial residues. J. Vet. Sci., 5: 5-9.

Sordillo, L.M., S.C. Nickerson and R.M. Akers, 1989. Pathology of Staphylococcus aureus mastitis during lactogenesis: Relationships with bovine mammary structure and function. J. Dairy Sci., 72: 228-240.

Yancey, R.J., M.S. Sanchez and C.W. Ford, 1991. Activity of antibiotics against Staphylococcus aureus within polymorphonuclear neutrophils. Eur. J. Clin. Microbiol. Infect. Dis., 10: 107-113.

Ziv, G. and M. Storper, 1985. Intramuscular treatment of subclinical staphylococcal mastitis in lactating cows with penicillin $G$, methicillin and their esters. J. Vet. Pharmacol. Ther., 8: 276-283. 